\title{
RELATIONSHIP BETWEEN POLYCHLORINATED DIBENZO-p-DIOXIN, POLYCHLORINATED DIBENZOFURAN, AND DIOXIN-LIKE POLYCHLORINATED BIPHENYL CONCENTRATIONS IN VEGETATION AND SOIL ON RESIDENTIAL PROPERTIES
}

\author{
Avery Demond, $* \dagger$ Timothy Towey, $\ddagger$ Peter Adriaens, $\dagger$ Xiaobo Zhong, $§$ Kristine Knutson, $\|$ Qixuan Chen, $\S$ \\ Biling Hong, $\|$ Brenda Gillespie, $§$ Alfred Franzblau, $\|$ David Garabrant, $\|$ James Lepkowski,\# \\ William LuKsemburg, $\dagger \dagger$ and Martha Maier $\dagger \dagger$ \\ $\dagger$ Department of Civil and Environmental Engineering, University of Michigan College of Engineering, Ann Arbor, Michigan 48109, USA \\ $\ddagger$ LimnoTech, Ann Arbor, Michigan, USA \\ §Department of Biostatistics, University of Michigan School of Public Health, Ann Arbor, Michigan, USA \\ ||Department of Environmental Health Sciences, University of Michigan School of Public Health, Ann Arbor, Michigan, USA \\ \#Institute for Social Research, University of Michigan, Ann Arbor, Michigan, USA \\ $\dagger \dagger$ Vista Analytical Laboratory, El Dorado Hills, California, USA
}

(Submitted 12 February 2010; Returned for Revision 21 March 2010; Accepted 18 July 2010)

\begin{abstract}
The University of Michigan Dioxin Exposure Study was undertaken to address concerns that the industrial discharge of dioxin-like compounds in the Midland, Michigan, USA area had resulted in the contamination of soil and vegetation in the Tittabawassee River floodplain and downwind of the incinerator in the City of Midland. The study included the analysis of 597 vegetation samples, predominantly grass and weeds, from residential properties selected through a multistage probabilistic sample design in the Midland area, and in Jackson and Calhoun Counties (Michigan), as a background comparison, for 29 polychlorinated dibenzo-p-dioxins (PCDDs), polychlorinated dibenzofurans (PCDFs), and polychlorinated biphenyls (PCBs). The mean toxic equivalent (TEQ) of the house perimeter vegetation samples ranged from 4.2 to $377 \mathrm{pg} / \mathrm{g}$. The ratio of TEQs (vegetation to soil) was about 0.3 , with a maximum of 3.5. Based on a calculation of the similarity of the congener patterns between the soil and the vegetation, it appeared that the source of the contamination on the vegetation was the surrounding soil. This conclusion was supported by linear regression analysis, which showed that the largest contributor to the $R^{2}$ for the outcome variable of $\log _{10}$ of the vegetation concentration was $\log _{10}$ of the surrounding soil concentration. Models of vegetation contamination usually focus on atmospheric deposition and partitioning. The results obtained here suggest that the deposition of soil particles onto vegetation is a significant route of contamination for residential herbage. Thus, the inclusion of deposition of soil particles onto vegetation is critical to the accurate modeling of contamination residential herbage in communities impacted by historic industrial discharges of persistent organic compounds. Environ. Toxicol. Chem. 2010;29:2660-2668. (C) 2010 SETAC
\end{abstract}

Keywords-Polychlorinated dibenzo-p-dioxins $\quad$ Polychlorinated dibenzofurans $\quad$ Polychlorinated biphenyls Vegetation Soil

\section{INTRODUCTION}

The University of Michigan Dioxin Exposure Study (UMDES) was undertaken in response to concerns among the population of Midland and Saginaw Counties in Michigan, USA, that the discharge of dioxin-like compounds from the Dow Chemical Company facilities in Midland had resulted in contamination of soil in the Tittabawassee River flood plain and areas of the city of Midland, leading to an increase in residents' body burdens of these compounds. Dow Chemical has operated in Midland since 1897, manufacturing a wide range of chemical products [1]. Historically, wastes from these manufacturing operations were incinerated, resulting in aerial deposition in the city of Midland, or were discharged either directly or indirectly to the Tittabawassee River and subsequently were deposited on residential property during flooding events. To analyze the relationship between this environmental contamination and residents' body burden, UMDES was a large multidisciplinary undertaking, including measurements of dioxin-

All Supplemental Data may be found in the online version of this article.

* To whom correspondence may be addressed

(averyd@umich.edu).

Published online 1 September 2010 in Wiley Online Library (wileyonlinelibrary.com). like compounds not only in soil and vegetation, but also in household dust and serum from populations in Midland, Saginaw and Bay Counties (Michigan) as the target areas, and from Jackson and Calhoun Counties (Michigan) as a background comparison. To account for additional factors that might impact the population's body burden of these compounds, the study also comprised the administration of a questionnaire covering age, weight, and smoking habits; residential, occupational, and dietary histories; and recreational habits including hunting, fishing, and water activities. From an exposure perspective, a fundamental issue is the degree of contamination of the environment. To help answer that question, a total of 2,081 soil samples from 766 residential properties were analyzed for the World Health Organization (WHO) 29 polychlorinated dibenzo- $p$ dioxins (PCDDs), polychlorinated dibenzofurans (PCDFs), and dioxin-like polychlorinated biphenyls (PCBs) congeners. In addition, 597 vegetation samples, obtained from a subset of the 766 properties, were also analyzed for the same congeners. The results of the soil measurements are reported in Demond et al. [2]. This analysis focuses on the vegetation measurements and their relationship to the soil concentrations.

The transport of dioxin-like compounds into above-ground vegetation from contaminated soil can occur through a variety of mechanisms: volatilization from the soil surface and 
adsorption onto the plant surface, root uptake and transport into the plant shoot, and contamination of the plant's foliage by soil [3]. It appears that volatilization followed by adsorption may be a major transport pathway in greenhouses, but in the field, this mechanism is thought to be of minor importance [4,5]. Similarly, root uptake and transport into the plant shoot may be important in some circumstances, such as with zucchini and pumpkin [4], but in most plants this is not a significant mechanism [6,7]. In the case of either of these mechanisms, the congener patterns of the soil and the vegetation differ, due to the preferential volatilization or uptake of particular congeners, resulting in a pattern shift in vegetation towards the lower chlorinated congeners. However, if good correspondence exists between the vegetation and soil patterns, it is thought that the primary mechanism of contamination is the deposition of soil particles on the vegetation [3].

Alternatively, vegetation may be impacted by atmospheric contamination from sources such as incinerators [8]. Because of the similarities between the congener pattern in plant material and that in the atmosphere, Lovett et al. [9] suggested that atmospheric deposition was an important mechanism. Wagrowski and Hites [10] noted that the concentration of PCDD/DFs seemed to be related to the compounds' saturated vapor pressure, suggesting that partitioning between the atmosphere and foliage may be the key process for the contamination of vegetation like corn, for example. Yet models accounting for atmospheric deposition and air to plant transfer of vapor phase constituents have been noted to work well for fresh fruit and above-ground green vegetables [11], but underpredict the concentrations of PCDD/DFs in grass [11,12]. This finding suggests the possibility of additional transport mechanisms in the case of grass.

Reports of the ratio of the toxic equivalent (TEQ) of the vegetation to that of the soil vary considerably and may depend on the mechanism of contamination. For example, in the case of above-ground vegetables a ratio of $1.7 \times 10^{-4}$ and $3.4 \times 10^{-3}$ were reported for lettuce by Hulster et al. [4] and Muller et al. [13], respectively. For zucchini, a plant that seems to uptake PCDD/DFs from the soil, a ratio of 0.023 to 0.14 was obtained, depending on the soil's TEQ and the fraction of organic carbon [4]. Prinz et al. [14] gave a transfer factor of 0.1 for PCDD/DFs for a range for fruits and vegetables in gardens and Meneses et al. [12] obtained a TEQ ratio of 0.27 for herbage samples collected in the vicinity of a municipal solid waste incinerator. Yet Schuhmacher et al. [15] observed that PCB concentrations in chard may exceed those in the surrounding soil, particularly in background areas, where atmospheric transport may be the dominant pathway. Similarly, Notarianni et al. [16] reported higher PCB concentrations in conifer needles than in soil, up to more than 20 times higher, in areas considered to be lowly impacted by industrial discharges.

The largest current source of dioxin-like compounds is incineration, originally municipal waste incinerators, but more recently backyard burning [17]. Thus, in this situation with historic soil contamination from past industrial incineration and periodic flooding, as well as potentially ongoing aerial deposition from municipal incineration or backyard burning, multiple mechanisms may be contributing to the contamination of vegetation around residences in the Midland area in Michigan. Consequently, the objective of the present study is to compare the concentration and congener profiles of dioxin-like compounds in vegetation and soil taken from residential property in an effort to elucidate their relationship.

\section{MATERIALS AND METHODS}

Vegetation samples were collected concurrently with soil samples from properties selected from five regions, designated as Floodplain (located in the 100-year FEMA [Federal Emergency Management Agency] floodplain of the Tittabawassee River or answering "yes" to the question, "Has your property ever been flooded by the Tittabawassee River?', ), Near Floodplain (located in a census block that contains a portion of the 100-year FEMA floodplain, but the properties themselves were not located in the floodplain), Plume (located in the incinerator plume downwind of the Dow facility, determined as outlined in [18]), Other Midland/Saginaw (located in Midland, Saginaw, or Bay Counties, but outside the above areas and any other river floodplain), and Jackson/Calhoun (located in Jackson or Calhoun Counties, $\approx 180 \mathrm{~km}$ southwest of the Midland area) (Fig. 1). Within each area, the census blocks to be sampled were first selected at random, followed by the selection at random of households within each census block. More details on the protocol of household selection can be found in Garabrant et al. [19].

Up to four sampling stations were located around the perimeter of the house, as shown in Demond et al. [2]. In addition, samples were taken in gardens (vegetation and flower) and near the river, if applicable, yielding a maximum of seven sampling stations at each residence: four house perimeter, two gardens, one near river. The cores from the house perimeter and the near river stations were extruded from the corer and separated into two strata: 0 to $2.54 \mathrm{~cm}(0-1$ inch) and 2.54 to $15.24 \mathrm{~cm}$ (1-6 inches), after which the respective strata were combined and homogenized. The cores from the gardens were not separated into strata, as it was assumed that soil in gardens is routinely turned over during planting. Ultimately, each residence yielded some or all of the following soil composites: house perimeter 0 to $2.54 \mathrm{~cm}$ composite (HP $0-1$ inch); house perimeter 2.54 to $15.24 \mathrm{~cm}$ composite (HP 1-6 inch); garden 0 to $15.24 \mathrm{~cm}$ composite (Garden); near river 0 to $2.54 \mathrm{~cm}$ composite (NR 0-1 inch); and near river 2.54 to $15.24 \mathrm{~cm}$ composite (NR 1-6 inch).

Roughly $500 \mathrm{ml}$ of vegetation was collected from each house perimeter sampling station, from within the same $0.94 \mathrm{~m}$ sampling ring as the soil samples, and placed in a Ziploc ${ }^{\circledR}$ bag. Approximately $1,000 \mathrm{ml}$ of vegetation were collected from the garden and near river stations, to ensure sufficient sample mass. Vegetables were rarely procured from the garden stations. Only a small fraction of the field sampling occurred during the time frame when garden vegetables were available; also, sampling often occurred in the absence of the homeowner, in which case permission may not have been available for procuring vegetables. Thus, most of the vegetation samples consisted of grass and weeds from the house perimeter (HP) and near river (NR) stations. The vegetation was cut off slightly above ground level. Any large soil clods attached to the vegetation were removed before composting, but no washing occurred. The samples were composted by set (HP, NR, and garden) using an electronic balance to ensure approximately equal masses from each station. The proportionate aliquots were then mixed by tossing in stainless steel bowls. The vegetation samples were shipped to Vista Analytical Laboratory (El Dorado Hills, CA) where they were analyzed by high-resolution gas chromatography/high-resolution mass spectrometry (HRGC/HRMS) using U.S. Environmental Protection Agency (U.S. EPA) methods 8290 [20] and 1668 [21] for the 29 PCDF, PCDD, dioxinlike PCB congeners listed by WHO [22]. In brief, the samples 


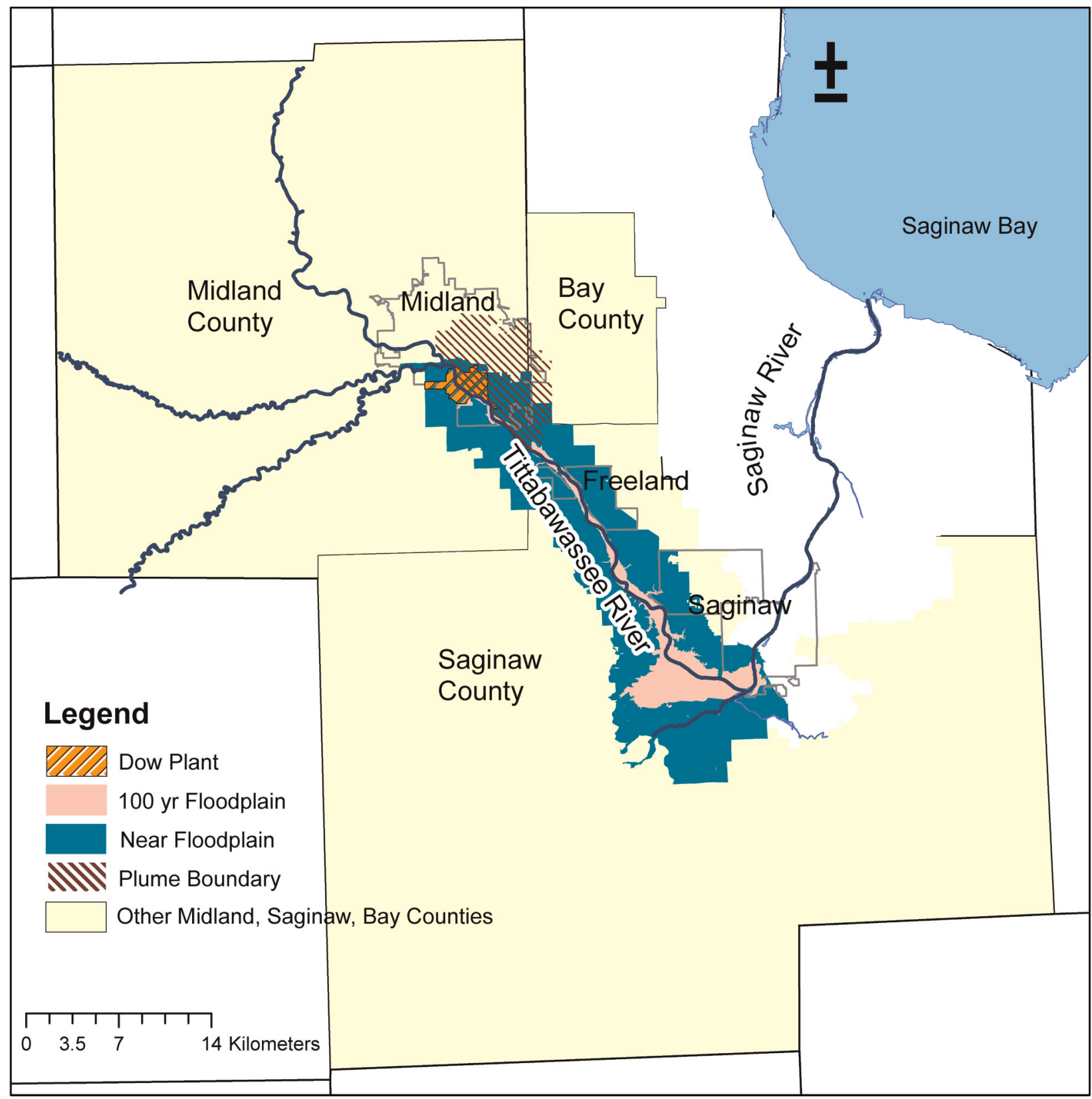

Fig. 1. Map showing University of Michigan Dioxin Exposure Study regions in Midland, Saginaw, and Bay Counties, Michigan, USA. [Color figure can be seen in the online version of this article, available at wileyonlinelibrary.com]

were homogenized and a 10 to 30 gram (wet wt) sample was spiked with a ${ }^{13} \mathrm{C}$-labeled internal standard and then soxhletextracted with toluene. The extracts were then spiked with the clean-up recovery standard, exchanged to hexane, and concentrated. The concentrates were then cleaned using a series of three columns: an acid-base silica gel and an acid alumina column, followed by a florisil column, if needed. The analytes in the concentrates were separated by a gas chromatograph and detected by a high-resolution mass spectrometer operating at a resolving power of 10,000 . An initial calibration curve was analyzed to demonstrate the linearity of the HRMS system over the calibration range and verified with a continuing calibration verification standard in each analytical batch. The recovery rates for the 29 congeners ranged from 72 to $95 \%$. If the concentration of a particular congener was below the limit of detection (LOD), the concentration was recorded as the LOD divided by $\sqrt{ } 2$ [23]. The mean and percentiles were also estimated using the reverse Kaplan-Meier method [24]; because the LODs were small, the results were virtually identical to those obtained using LOD divided by $\sqrt{ } 2$. The measured concentrations were then adjusted using population sampling weights to reflect the fact that the soil samples were obtained from a probabilistic subset of the areas' households.

The contamination in the vegetation and in the soil was compared in three ways. First, to compare the magnitude of the concentrations, the mean, median, 75 th, and 95 th percentiles for the ratio of the concentrations of vegetation to soil were computed for the TEQ ${ }_{\text {DFP-2005 }}$ (the subscript DFP refers to the 29 PCDD/DFs, and PCBs listed by WHO; 2005 refers to the toxic equivalency factors [TEFs] promulgated by WHO in 2005 [22]) as well as for 2,3,7,8-TCDD, the top contributor to the soil TEQ $\mathrm{DFP}_{2005}$ in the plume; 2,3,4,7,8-PeCDF, the top contributor in the Floodplain; and PCB 126, the top contributor in Jackson/Calhoun [2]. In addition, the congener patterns were compared visually and quantitatively by computing the cosine of the angle between the vectors 
comprising the soil and vegetation congener concentrations. To compare samples $i$ and $j$, with $n$ congeners, the $\cos \theta$ parameter was calculated as:

$$
\cos \theta=\frac{\sum_{k=1}^{n} \chi_{i k} \chi_{j k}}{\left[\sum_{k=1}^{n} \chi_{i k}^{2} \sum_{k=1}^{n} \chi_{j k}^{2}\right]^{1 / 2}}
$$

where $\chi$ is the mass fraction of congener $k$ to the total mass of PCDD/DFs and PCBs. This parameter is based on a geometric calculation between two vectors with a value of 0 , meaning that the patterns are completely dissimilar, and a value of 1 , meaning that the patterns are identical [25]. Finally, stepwise linear regression was carried out using SAS statistical software (v. 9.1) employing $\log _{10}$ of the vegetation concentration (TEQDFP-2005, 2,3,7,8-TCDD, 2,3,4,7,8-PeCDF, and PCB 126) as the outcome variables and $\log _{10}$ concentrations of the corresponding soil composites as predictor variables. The concentrations were logtransformed, as that resulted in distributions that were closer to normal and improved the amount of variation explained by the regression model. In addition, information drawn from the UMDES questionnaire, such as property use (use of weed killers, use of property as a farm, occurrence of trash or yard waste burning, use of woodburning fireplace, fire damage to property, incidences of flooding, ownership of pets), information drawn from field notes (sampling season), precipitation data (elapsed time since last rain, cumulative rain in last $3 \mathrm{~d}$ ), and region (floodplain, near floodplain, plume, other Midland/Saginaw and Jackson/Calhoun) were used as predictor variables.

\section{RESULTS AND DISCUSSION}

\section{Ratio of vegetation-to-soil concentrations}

A total of 597 predominantly grass and weed samples obtained from around the house (HP) $(n=416)$, in gardens (Garden) $(n=18)$, and near the Tittabawassee River (NR) $(n=163)$ were analyzed. Another 22 samples were submitted as blind duplicates with the average relative percent difference equaling 49\%. Most studies dealing with vegetation analysis do not give any statistics for blind duplicates, so there is little directly comparative information. Van den Berg et al. [22] cite that many duplicate GC-MS analyses for these compounds have an uncertainty that range from 10 to $25 \%$, for more homogeneous materials such as breast milk and fish filets. Furthermore, it is documented that the error can be greater with vegetation samples, with Welsch-Pausch et al. [7] giving the coefficient for variation of parallel grass samples as 2.5 times that of gas samples. A similar phenomenon was observed in this study in that the percent relative error for the soil samples was about $15 \%$ [2], whereas that for the vegetation samples was $49 \%$.

The arithmetic mean, median, 75th and 95th percentiles, and the range of the population-weighted TEQDFP-2005, 2,3,7,8TCDD, 2,3,4,7,8-PeCDF, and PCB 126 concentrations are given in Table 1. The same statistics for the HP samples (along with the number below LOD and the median LOD) for all 29

Table 1. Arithmetic mean, standard error (in parentheses), median, 75th, and 95th percentiles (in italics) and range of vegetation concentrations for house perimeter (all areas), near river (floodplain only), garden (floodplain, near floodplain, and other Midland/Saginaw only) composites (in pg/g dry wt)

\begin{tabular}{|c|c|c|c|c|}
\hline Composite type & $\mathrm{TEQ}_{\mathrm{DFP}-2005}$ & 2,3,7,8-TCDD & $2,3,4,7,8-\mathrm{PeCDF}$ & PCB 126 \\
\hline Floodplain HP & $14.2(3.4)$ & $0.6(0.1)$ & $17.0(5.0)$ & $3.3(0.3)$ \\
\hline$n=188$ & $\begin{array}{c}3.4,7.4,50.2 \\
0.4-1430\end{array}$ & $\begin{array}{c}0.3,0.6,1.9 \\
\text { ND-8.1 }\end{array}$ & $\begin{array}{l}2.1,8.0,70.5 \\
\text { ND-2100 }\end{array}$ & $\begin{array}{c}2.3,3.3,10.9 \\
\text { ND-32.1 }\end{array}$ \\
\hline Plume HP & $37.5(12.7)$ & $10.7(2.5)$ & $19.4(13.6)$ & $28.0(17.0)$ \\
\hline$n=36$ & $\begin{array}{c}18.3,31.1,125 \\
0.8-269\end{array}$ & $\begin{array}{c}7.5,15.3,29.4 \\
\text { ND-56.7 }\end{array}$ & $\begin{array}{c}2.1,7.9,33.8 \\
\text { ND-311 }\end{array}$ & $\begin{array}{c}5.3,10.7,308 \\
\text { ND-308 }\end{array}$ \\
\hline Near floodplain HP & $377(354)$ & $0.7(0.3)$ & $529(501)$ & $3.5(0.7)$ \\
\hline$n=69$ & $\begin{array}{c}3.310 .1,152 \\
0.6-7995\end{array}$ & $\begin{array}{c}0.30 .5,6.1 \\
\text { ND-6.2 }\end{array}$ & $\begin{array}{c}2.4,8.2,226 \\
\text { ND- } 11300\end{array}$ & $\begin{array}{c}1.9,3.0,14.2 \\
\text { ND-56.8 }\end{array}$ \\
\hline Other M/S HP & $4.2(0.4)$ & $0.6(0.2)$ & $2.2(0.4)$ & $5.3(0.7)$ \\
\hline$n=71$ & $\begin{array}{l}3.3,5.1,10.1 \\
1.0-27.5\end{array}$ & $\begin{array}{c}0.4,0.6,2.1 \\
\text { ND-6.1 }\end{array}$ & $\begin{array}{c}1.4,2.6,5.5 \\
\text { ND-37.9 }\end{array}$ & $\begin{array}{c}3.3,7.0,15.1 \\
\text { ND-63.9 }\end{array}$ \\
\hline Jackson/Calhoun HP & $4.5(0.6)$ & $0.3(0.0)$ & $1.6(0.3)$ & $14.8(2.9)$ \\
\hline $\mathrm{N}=52$ & $\begin{array}{c}3.3,6.7,8.7 \\
0.6-25.9\end{array}$ & $\begin{array}{l}0.2,0.3,0.6 \\
\text { ND-4.1 }\end{array}$ & $\begin{array}{l}0.8,2.5,4.1 \\
\text { ND-7.2 }\end{array}$ & $\begin{array}{c}7.2,15.1,60.8 \\
1.1-210\end{array}$ \\
\hline Overall HP & $11.4(4.1)$ & $1.4(0.3)$ & $9.5(5.6)$ & $10.8(2)$ \\
\hline$n=416$ & $\begin{array}{c}3.5,6.6,20.9 \\
0.4-7995\end{array}$ & $\begin{array}{l}0.3,0.6,7.0 \\
\text { ND-56.7 }\end{array}$ & $\begin{array}{c}1.2,3.1,7.2 \\
\text { ND-11300 }\end{array}$ & $\begin{array}{c}4.3,9.3,37.7 \\
\text { ND-308 }\end{array}$ \\
\hline Floodplain NR & $49.5(16.4)$ & $2.5(1.3)$ & $60.7(21.4)$ & $4.1(0.8)$ \\
\hline$n=163$ & $\begin{array}{l}3.1,13.5,222 \\
0.2-1724\end{array}$ & $\begin{array}{l}0.3,0.6,4.7 \\
\text { ND- } 128\end{array}$ & $\begin{array}{l}1.7,10.9,315 \\
\text { ND-2240 }\end{array}$ & $\begin{array}{l}2.2,4.2,15.0 \\
\text { ND-63.1 }\end{array}$ \\
\hline Floodplain garden & $17.5(11)$ & $0.7(0.4)$ & $22(16.8)$ & $2.1(0.4)$ \\
\hline$n=13$ & $\begin{array}{c}2.1,15.1,90.9 \\
0.8-90.9\end{array}$ & $\begin{array}{l}0.2,0.5,3.6 \\
\text { ND-3.6 }\end{array}$ & $\begin{array}{c}0.9,3.6,137 \\
\text { ND-137 }\end{array}$ & $\begin{array}{c}1.7,2.1,4.9 \\
\text { ND-6.8 }\end{array}$ \\
\hline Near floodplain garden & $8.0(4.6)$ & $0.6(0.3)$ & $7.6(5.1)$ & $1.3(0.4)$ \\
\hline$n=4$ & $\begin{array}{c}3.6,8.9,28.3 \\
0.6-28.3\end{array}$ & $\begin{array}{l}0.2,0.8,2.0 \\
\text { ND-2.0 }\end{array}$ & $\begin{array}{c}\text { 4.6, } 4.6,31.7 \\
\text { ND-31.7 }\end{array}$ & $\begin{array}{c}0.7,2.3,2.5 \\
\text { ND-2.5 }\end{array}$ \\
\hline $\begin{array}{l}\text { Other M/S garden* } \\
n=1\end{array}$ & 3.8 & 0.9 & 0.8 & 1.4 \\
\hline Overall garden & $5.9(1.7)$ & $0.9(0.1)$ & $4.2(2.6)$ & $1.5(0.1)$ \\
\hline$n=18$ & $\begin{array}{c}3.8,3.8,15.1 \\
0.6-90.9\end{array}$ & $\begin{array}{l}0.9,0.9,0.9 \\
\text { ND-3.6 }\end{array}$ & $\begin{array}{l}0.8,0.8,4.6 \\
\text { ND-137 }\end{array}$ & $\begin{array}{c}1.4,1.4,2.3 \\
\text { ND-6.8 }\end{array}$ \\
\hline
\end{tabular}

$\mathrm{HP}=$ house perimeter; M/S = Midland/Saginaw Counties (Michigan, USA); $n=$ number; ND = nondetectable; NR $=$ near river; PCB = polychlorinated biphenyl; PeCDF $=$ pentachlorinated dibenzofuran; TCDD $=$ tetrachlorinated dibenzo- $p$-dioxin; TEQ $=$ toxic equivalent.

* No statistics reported because only one sample. 
WHO congeners are given in the Supplemental Data, Table S1. Table 1 shows that the HP and the NR composites from the contaminated regions, the floodplain and the plume, have a higher mean TEQ ${ }_{\mathrm{DFP}-2005}$ than that of the background region, Jackson/Calhoun, based on the $t$ score with a significance level of 0.01. The HP composites from the near floodplain have the highest mean TEQ, but because of the high standard error, the mean was determined to not be statistically significantly higher than the mean in Jackson-Calhoun, at a significance level of 0.01. The high standard error for the near floodplain is undoubtedly due to an outlier, as the median value for the vegetation in the near floodplain is only $3.3 \mathrm{pg} / \mathrm{g}$, but the maximum value of all the vegetation composites of $7,995 \mathrm{pg} / \mathrm{g}$ was measured on a composite from the near floodplain. In fact, the median TEQDFP-2005 of all the composite sets is similar, even that of Jackson/Calhoun, with the exception of the composites from the plume, which show an elevated median.

Table 2 shows the statistics for the ratio of the vegetation TEQ ${ }_{\text {DFP-2005 }}, 2,3,7,8-T C D D, 2,3,4,7,8-P e C D F$, and PCB 126 concentrations to the corresponding $0-1$ inch concentration in the soil. These show that the overall mean TEQ $0.31,0.28$, and 0.21 for the HP, NR, and garden composites, respectively. These values correspond well to the ratio of 0.27 reported in [12] for herbage samples, which Hulster and Marschner [3] infer is indicative of contamination directly by soil particles. The maximum ratio for TEQ ${ }_{\mathrm{DFP}-2005}$ is 3.5, whereas for PCB 126, the maximum ratio is 5.1. These values support the observations [15] that vegetation may have higher concentrations than the surrounding soil, but the phenomenon of 20 times higher PCB concentrations in vegetation [16] than in the surrounding soil was not observed here. These ratios are greater than those typically observed in studies of above-ground garden vegetables not directly impacted by soil particles, such as that for lettuce of approximately $2 \times 10^{-3}[3,13]$. In fact, the TEQ ratios measured here for some above-ground vegetables were $7.51 \times 10^{-3}$ for a tomato harvested in floodplain, where the soil HP 0 to 1 inch TEQ ${ }_{D F P-2005}$ equaled $167.8 \mathrm{pg} / \mathrm{g}$, and $4.62 \times 10^{-2}$ for a cabbage, harvested in near floodplain where the soil HP 0 to 1 inch TEQ mean ratios between the vegetation and soil concentrations reported in Table 2 are higher than those that may be expected in above-ground vegetables that were grown in gardens in the region.

\section{Comparison of congener patterns in soil and vegetation}

A qualitative comparison of the congener patterns in the soil and vegetation is shown in Figure 2. This figure suggests that there are distinctly different patterns in the floodplain, plume, and Jackson/Calhoun. The floodplain pattern, where the principal means of contamination was through the deposition of contaminated sediment, is distinguished by its relatively high concentrations of furans, whereas the plume pattern, where the contamination was caused by the deposition from incineration, is distinguished by its level of 2,3,7,8-TCDD, and the Jackson/ Calhoun pattern, where no industrial source of dioxin-like compounds is known, is dominated by PCBs. This differentia-

Table 2. Arithmetic mean, standard error (in parentheses), median, 75th, and 95th percentiles (in italics) and range of ratio of vegetation concentration to corresponding soil concentration in 0 to 1 inch composite for house perimeter (all areas), near river (floodplain only), garden (floodplain, near floodplain and other Midland/Saginaw only) (in pg/g dry wt)

\begin{tabular}{|c|c|c|c|c|}
\hline Composite Set & TEQDFP-2005 & 2,3,7,8-TCDD & $2,3,4,7,8-\mathrm{PeCDF}$ & PCB 126 \\
\hline Floodplain HP & $0.342(0.021)$ & $0.299(0.018)$ & $0.331(0.036)$ & $0.635(0.034)$ \\
\hline \multirow[t]{2}{*}{$n=188$} & $0.275,0.467,0.905$ & $0.237,0.396,0.851$ & $0.244,0.405,0.849$ & $0.52,0.817,1.376$ \\
\hline & $0.009-1.623$ & $0.033-1.672$ & $0.009-5.411$ & $0.082-3.423$ \\
\hline Plume HP & $0.284(0.036)$ & $0.260(0.037)$ & $0.343(0.044)$ & $0.508(0.071)$ \\
\hline \multirow[t]{2}{*}{$n=36$} & $0.251,0.487,0.679$ & $0.234,0.398,0.708$ & $0.315,0.453,0.087$ & $0.453,0.589,0.920$ \\
\hline & $0.013-0.915$ & $0.005-0.777$ & $0.021-1.435$ & $0.071-5.134$ \\
\hline Near floodplain HP & $0.376(0.061)$ & $0.347(0.043)$ & $0.351(0.058)$ & $0.676(0.049)$ \\
\hline \multirow[t]{2}{*}{$n=69$} & $0.241,0.434,1.275$ & $0.241,0.419,0.942$ & $0.233,0.413,1.13$ & $0.593,0.890,1.392$ \\
\hline & $0.009-3.476$ & $0.019-1.944$ & $0.004-3.383$ & $0.094-2.169$ \\
\hline Other M/S HP & $0.222(0.02)$ & $0.216(0.022)$ & $0.224(0.027)$ & $0.450(0.033)$ \\
\hline \multirow[t]{2}{*}{$n=71$} & $0.173,0.275,0.553$ & $0.169,0.263,0.557$ & $0.180,0.275,0.522$ & $0.407,0.546,1.052$ \\
\hline & $0.018-1.022$ & $0.033-0.964$ & $0.013-2.667$ & $0.052-1.374$ \\
\hline Jackson/Calhoun HP & $0.438(0.046)$ & $0.616(0.072)$ & $0.411(0.047)$ & $0.638(0.062)$ \\
\hline \multirow[t]{2}{*}{$n=52$} & $0.284,0.680,1.097$ & $0.538,0.855,2.023$ & $0.307,0.619,1.056$ & $0.505,0.789,1.531$ \\
\hline & $0.019-2.489$ & $0.005-2.783$ & $0.005-2.483$ & $0.059-3.111$ \\
\hline Overall HP & $0.309(0.021)$ & $0.365(0.035)$ & $0.305(0.023)$ & $0.529(0.028)$ \\
\hline \multirow[t]{2}{*}{$n=416$} & $0.219,0.373,0.948$ & $0.214,0.485,1.039$ & $0.219,0.384,0.812$ & $0.454,0.634,1.231$ \\
\hline & $0.009-3.476$ & $0.005-2.783$ & $0.004-5.411$ & $0.052-5.134$ \\
\hline Floodplain NR & $0.282(0.022)$ & $0.454(0.160)$ & $0.265(0.025)$ & $0.554(0.033)$ \\
\hline \multirow[t]{2}{*}{$n=163$} & $0.217,0.372,0.768$ & $0.215,0.421,0.860$ & $0.172,0.383,0.682$ & $0.455,0.765,1.344$ \\
\hline & $0.003-1.835$ & $0.004-23.351$ & $0.002-2.364$ & $0.021-2.625$ \\
\hline Floodplain garden & $0.302(0.108)$ & $0.393(0.101)$ & $0.269(0.119)$ & $0.654(0.180)$ \\
\hline \multirow[t]{2}{*}{$n=13$} & $0.142,0.562,1.284$ & $0.365,0.638,1.236$ & $0.109,0.419,1.459$ & $0.439,0.868,2.103$ \\
\hline & $0.008-1.284$ & $0.045-1.236$ & $0.004-1.459$ & $0.043-2.103$ \\
\hline Near floodplain Garden & $0.267(0.121)$ & $0.312(0.116)$ & $0.274(0.123)$ & $0.478(0.185)$ \\
\hline \multirow[t]{2}{*}{$n=4$} & $0.270,0.501,0.509$ & $0.298,0.534,0.586$ & $0.260,0.508,0.559$ & $0.469,0.829,0.909$ \\
\hline & $0.018-0.509$ & $0.065-0.586$ & $0.016-0.559$ & $0.064-0.909$ \\
\hline \multicolumn{5}{|l|}{$n=1$} \\
\hline Overall garden & $0.232(0.019)$ & $0.206(0.018)$ & $0.369(0.021)$ & $0.540(0.031)$ \\
\hline \multirow{2}{*}{$n=18$} & $0.214,0.214,0.509$ & $0.159,0.159,0.586$ & $0.396,0.396,0.457$ & $0.521,0.521,0.868$ \\
\hline & $0.008-1.284$ & $0.045-1.236$ & $0.004-1.459$ & $0.043-2.103$ \\
\hline
\end{tabular}

Refer to Table 1 for definitions.

$\mathrm{HP}=$ house perimeter; $\mathrm{M} / \mathrm{S}=$ Midland/Saginaw Counties (Michigan, USA); $n=$ number; NR $=$ near river.

* No statistics reported because only one sample. 
Soil 0-2.54 cm

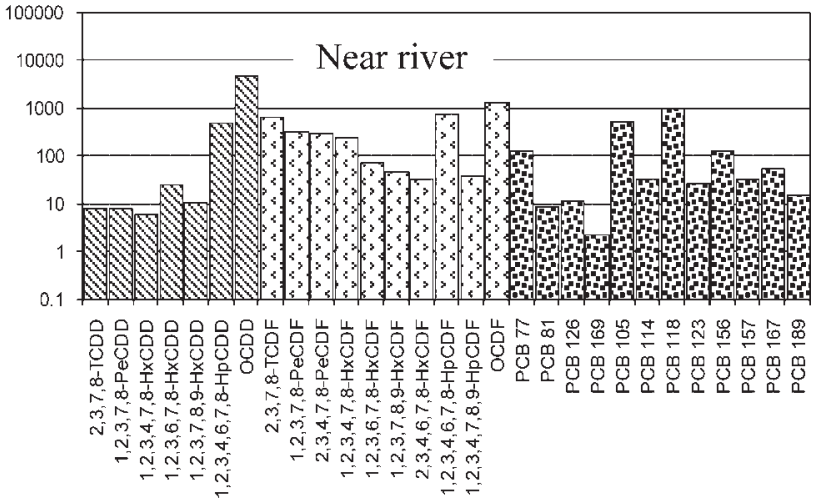

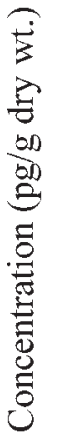
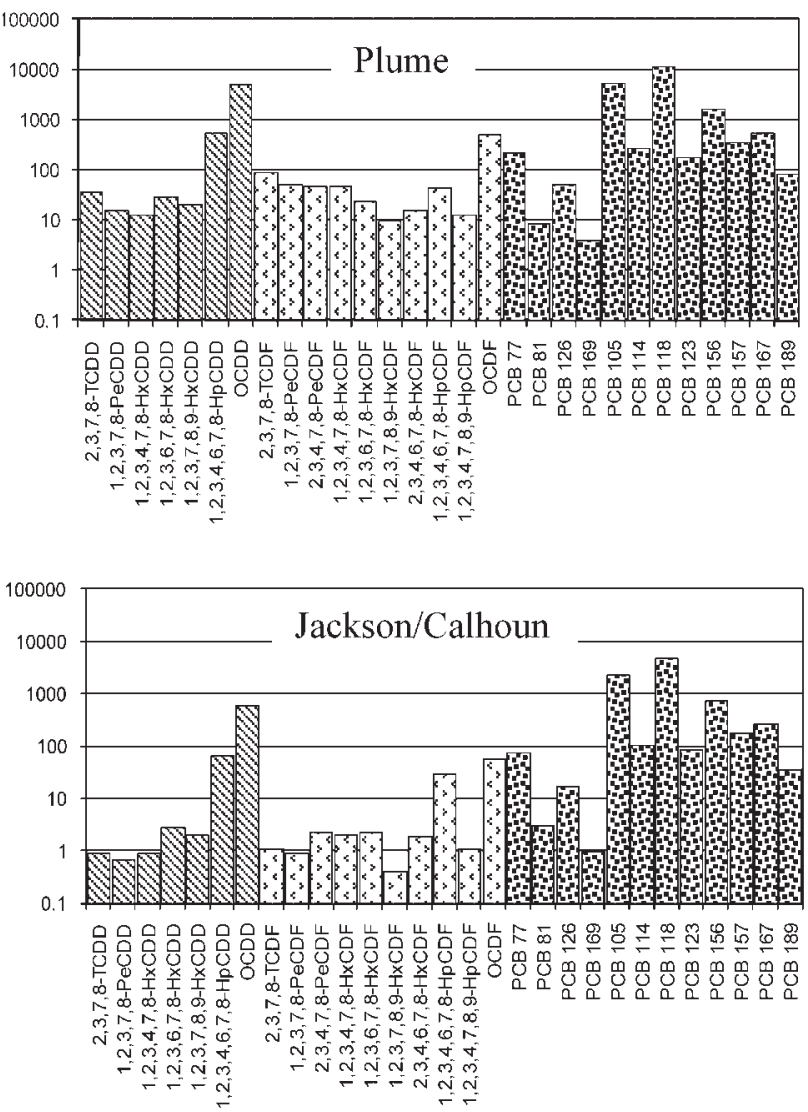

Vegetation
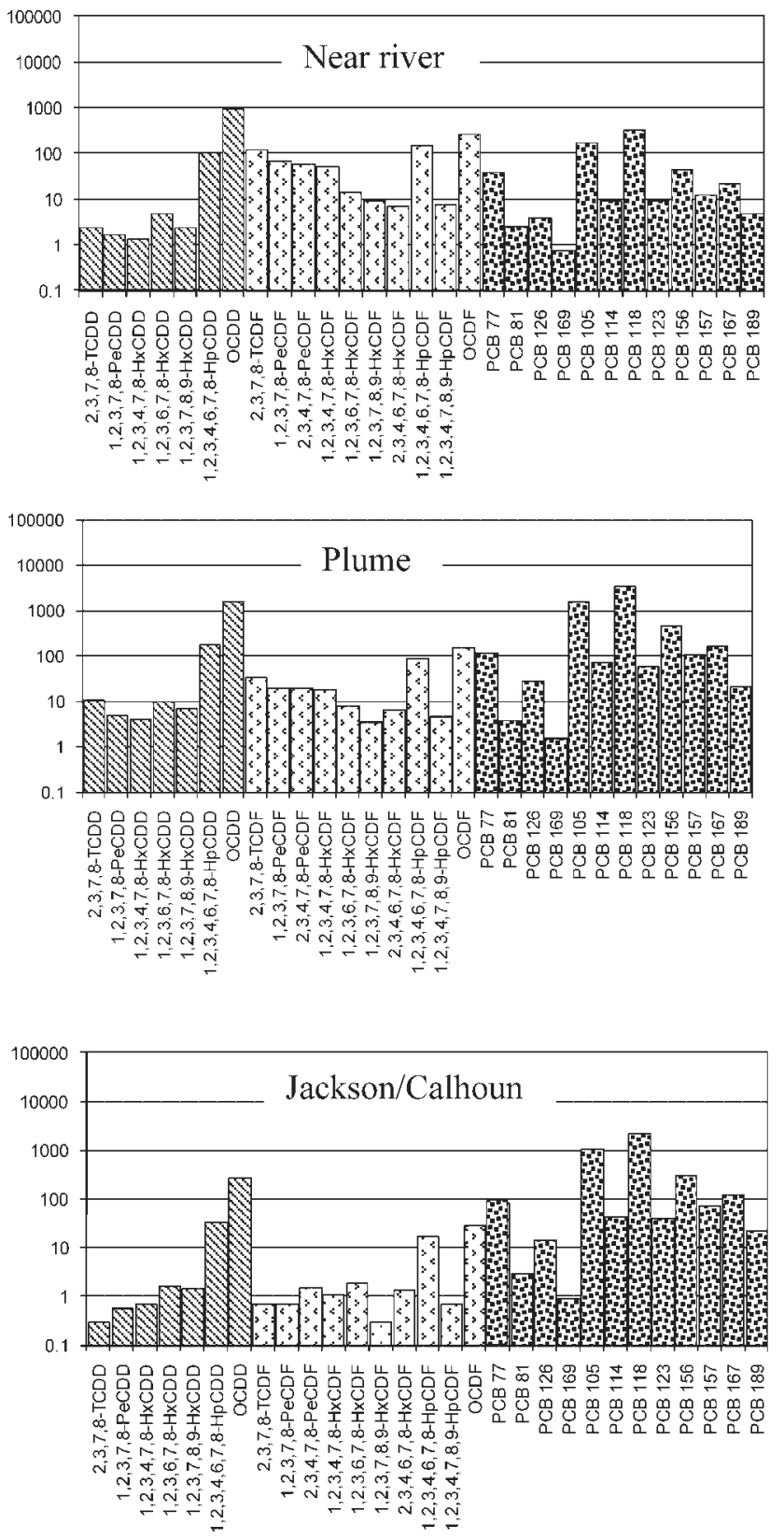

Fig. 2. Congener profiles from representative soil and vegetation composites from the near river (floodplain) station, and house perimeter (plume and Jackson/ Calhoun) stations. $\mathrm{CDD}=$ chlorinated dibenzo- $p$-dioxin; $\mathrm{CDF}=$ chlorinated dibenzofuran; $\mathrm{T}=$ tetra; $\mathrm{Pe}=\mathrm{penta} ; \mathrm{Hx}=\mathrm{hexa} ; \mathrm{Hp}=\mathrm{hepta} ; \mathrm{O}=\mathrm{octa}$; $\mathrm{PCB}=$ polychlorinated biphenyl.

tion of patterns is corroborated by the hierarchical cluster analysis performed on the soil samples [26] which defined clusters related to the Tittabawassee River contamination containing elevated furan levels, clusters from the plume containing elevated 2,3,7,8-TCDD and clusters representing background patterns. Regardless of region, there is considerable visual similarity between the patterns in the vegetation and in the soil, suggesting that the preponderance of contamination on the vegetation is through the deposition of soil particles on the vegetation. This similarity is demonstrated quantitatively by the values of the $\cos \theta$ parameter (Eqn. 1) presented in Table 3. The parameter was calculated using three groupings of congeners: the PCDD/DFs, the PCBs, and all 29 congeners. The values in all cases are above 0.8 , confirming the visual observation that the soil and vegetation patterns are similar. The values for the comparisons involving the PCDD/DFs and the PCBs are all greater than 0.98 . However, the degree of similarity decreases when all 29 congeners are considered, particularly in the areas impacted by contaminated river sediment. This decrease in similarity may be related to the higher ratio of vegetation-tosoil concentrations for PCBs in these areas (Table 2). For example, the ratio of concentrations for the floodplain HP composites is 0.635 for PCB 126, whereas it is 0.299 for 2,3,7,8 TCDD. In contrast, in Jackson/Calhoun the corresponding ratios are 0.638 and 0.616 . Thus, in the case of the floodplain the PCBs are disproportionately represented in the vegetation, making the aggregate congener pattern less similar than the $\mathrm{PCDD} / \mathrm{DFs}$ or the PCB patterns. These results also suggest an 
Table 3. Average values of $\cos \theta$ parameter comparing the patterns of the 0 to 1 inch soil composite and the corresponding vegetation composite

\begin{tabular}{lccc} 
Composite type & PCDDs/PCDFs & PCBs & PCDDs/PCDFs/PCBs \\
\hline Floodplain NR & 0.993 & 0.991 & 0.887 \\
Floodplain HP & 0.991 & 0.991 & 0.889 \\
Plume HP & 0.998 & 0.993 & 0.915 \\
Near floodplain HP & 0.981 & 0.990 & 0.837 \\
Other M/S HP & 0.996 & 0.994 & 0.921 \\
Jackson/Calhoun HP & 0.997 & 0.993 & 0.935 \\
\hline
\end{tabular}

$\mathrm{HP}=$ house perimeter; $\mathrm{M} / \mathrm{S}=$ Midland/Saginaw Counties (Michigan, $\mathrm{USA}) ; \mathrm{NR}=$ near river.

$\mathrm{PCDD}=$ polychlorinated $\quad$ dibenzo- $p$-dioxin $; \quad \mathrm{PCDF}=$ polychlorinated dibenzofuran; $\mathrm{PCB}=$ polychlorinated biphenyl.

additional source of PCBs, other than direct deposition of soil. If a typical ratio of vegetation-to-soil concentrations in the case of contaminated soil deposition is approximately 0.3 , then the higher ratio of approximately 0.6 may be characteristic of background atmospheric contamination.

\section{Linear regression analysis}

To further quantify the relationship between the vegetation and soil, a linear regression analysis was performed for the HP and NR samples, the results of which are shown in Tables 4 and 5. The largest contributor to the $R^{2}$ was the HP 1 to 6 inch soil concentration in the case of TEQ 2,3,4,7,8-PeCDF, but the HP 0 to 1 inch soil concentration in the case of PCB 126. In the case of NR vegetation, the biggest contributor was the NR 0 to 1 inch soil concentration in all cases. The difference is probably not meaningful because the concentrations in the 0 to 1 inch and the 1 to 6 inch soil composites are highly correlated, as indicated by the fact that the correlation coefficients were greater than 0.88 in all cases. Other variables that proved to be significant and stable predictors were region and season. The two regions that are known to be contaminated, the floodplain and plume, generally had higher regression coefficients ( $\beta$ values) for the region variable than the near floodplain and other Midland/Saginaw. The $\beta$ values were higher for the plume than for the floodplain, with the highest $\beta$ value for $2,3,7,8$-TCDD, the dominant contributor to the TEQ in the plume. This reflects the more homogeneous distribution of contamination in the plume, relative to the floodplain, as ascertained by the soil sampling. Again, PCB 126 seems to display different behavior, with smaller and predominantly negative values of $\beta$, suggesting an inverse association with the Midland/Saginaw regions. With respect to season, the values of $\beta$ are roughly of the same magnitude, but are positive for the fall and negative for the spring. Because the rainfall variables (elapsed time since last rain, cumulative rain in last 3 d) did not enter into any models, the association between $\log _{10}$ vegetation concentration and season may be through another effect, perhaps the age of the grass, vegetation length, or cumulative yard usage during Michigan's temperate months (April-October). Other variables that entered into some of the models were the presence of pets, trash burning, fire damage, and flooding by the Tittabawassee River, but the $R^{2}$ difference for all of these variables was consistently under 2.00.

\section{CONCLUSIONS}

A total of 597 grass and weed samples, obtained from residential properties in four regions around Midland Michigan and in another region, Jackson and Calhoun counties, as a background comparison, were analyzed for $29 \mathrm{PCDD} / \mathrm{DFs}$ and dioxin-like PCB congeners. The results showed that the mean TEQ the regions known to be contaminated, the floodplain and the plume. The ratio of the concentration of the vegetation to that of the 0 to 1 inch soil composite was $0.31,0.28$, and 0.21 for the $\mathrm{HP}, \mathrm{NR}$, and garden composites, respectively, very similar to the ratio of 0.27 reported previously [12] for herbage. Values for above-ground garden vegetables on the order of $1 \times 10^{-2}$ were measured here, similar to those reported by others $[4,13]$. The linear regression modeling showed that the principal contributor

Table 4. Linear regression results for models predicting $\log _{10}$ concentration of HP vegetation composites showing only significant $(p<0.10)$ and stable parameters

\begin{tabular}{|c|c|c|c|c|c|c|c|c|c|c|c|c|}
\hline \multirow[b]{2}{*}{ Parameter } & \multicolumn{3}{|c|}{ TEQDFP-2005 } & \multicolumn{3}{|c|}{$2,3,7,8-\mathrm{TCDD}$} & \multicolumn{3}{|c|}{$2,3,4,7,8-\mathrm{PeCDF}$} & \multicolumn{3}{|c|}{ PCB 126} \\
\hline & $\beta$ & $p$ value & $\begin{array}{c}R^{2} \\
\text { difference }\end{array}$ & $\beta$ & $p$ value & $\begin{array}{c}R^{2} \\
\text { difference }\end{array}$ & $\beta$ & $p$ value & $\begin{array}{c}R^{2} \\
\text { difference }\end{array}$ & $\beta$ & $p$ value & $\begin{array}{c}R^{2} \\
\text { difference }\end{array}$ \\
\hline $\log _{10}$ soil concn. HP 0-1 inch & & & & & & & & & & 0.761 & 0.000 & 62.82 \\
\hline $\log _{10}$ soil concn. HP $1-6$ inch & 0.320 & 0.000 & 29.27 & 0.457 & 0.000 & 59.95 & 0.527 & 0.000 & 48.43 & & & \\
\hline Region $^{\text {a }}-\mathrm{FP}$ & 0.120 & 0.000 & 12.23 & 0.212 & 0.000 & 8.27 & 0.188 & 0.000 & 3.85 & 0.042 & 0.001 & 2.59 \\
\hline Region $^{\mathrm{a}}$-Near FP & 0.023 & & & -0.007 & & & 0.126 & & & -0.100 & & \\
\hline Region $^{\text {a }}$-Other MS & -0.122 & & & -0.015 & & & -0.119 & & & -0.169 & & \\
\hline Region ${ }^{\text {a }}$-Plume & 0.375 & & & 0.649 & & & 0.180 & & & -0.089 & & \\
\hline Season ${ }^{\mathrm{b}}$-Fall & 0.103 & 0.000 & 4.00 & & & & 0.100 & 0.000 & 3.48 & 0.138 & 0.000 & 3.03 \\
\hline Season ${ }^{\mathrm{b}}$-Spring & -0.129 & & & & & & -0.171 & & & -0.148 & & \\
\hline Pets ${ }^{c}$ & 0.010 & 0.028 & 1.84 & 0.011 & 0.021 & 1.25 & & & & 0.012 & 0.016 & 1.47 \\
\hline Trash burned $^{\mathrm{d}}$ & -0.016 & 0.000 & 1.03 & & & & & & & & & \\
\hline Fire damage ${ }^{\mathrm{e}}$ & 0.259 & 0.015 & 1.08 & & & & 0.158 & 0.038 & 0.25 & 0.329 & 0.025 & 1.21 \\
\hline Flooded by river $^{\mathrm{f}}$ & & & & -0.270 & 0.000 & 0.55 & & & & -0.198 & 0.001 & 0.47 \\
\hline$R^{2}$ of overall model & & & 49.45 & & & 70.02 & & & 56.01 & & & 71.59 \\
\hline
\end{tabular}

Refer to Table 1 for definitions.

$\mathrm{FP}=$ floodplain; $\mathrm{HP}=$ house perimeter; $\mathrm{MS}=$ Midland/Saginaw Counties (Michigan, USA).

${ }^{a}$ Region is relative to the control or background region, Jackson/Calhoun Counties (Michigan, USA). Given $p$ value and $R^{2}$ difference are for the season variable.

${ }^{\mathrm{b}}$ Season is relative to summer. Given $p$ value and $R^{2}$ difference are for the season variable.

"A "yes" answer to the question, "Did you ever live on a property where pets frequently went in and out of your home?"

"A "yes" answer to the question, "Did you ever live on a property where trash or yard waste was burned?"

"A "yes", answer to the question, "Was a property that you lived in ever damaged by a fire while you lived there?"

"A "yes" answer to the question, "To your knowledge, has any portion of your property ever been flooded by the Tittabawassee River?" 
Table 5. Linear regression results for models predicting $\log _{10}$ concentration of NR vegetation composites showing only significant $(p<0.10)$ and stable parameters

\begin{tabular}{|c|c|c|c|c|c|c|c|c|c|c|c|c|}
\hline \multirow[b]{2}{*}{ Parameter } & \multicolumn{3}{|c|}{ TEQ } & \multicolumn{3}{|c|}{ 2,3,7,8-TCDD } & \multicolumn{3}{|c|}{$2,3,4,7,8-\mathrm{PeCDF}$} & \multicolumn{3}{|c|}{ PCB 126} \\
\hline & $\beta$ & $p$ value & $\begin{array}{c}R^{2} \\
\text { difference }\end{array}$ & $\beta$ & $p$ value & $\begin{array}{c}R^{2} \\
\text { difference }\end{array}$ & $\beta$ & $p$ value & $\begin{array}{c}R^{2} \\
\text { difference }\end{array}$ & $\beta$ & $p$ value & $\begin{array}{c}R^{2} \\
\text { difference }\end{array}$ \\
\hline $\log _{10}$ soil concn. NR 0-1 inch & 0.760 & 0.000 & 70.37 & 0.617 & 0.000 & 46.50 & 0.822 & 0.000 & 75.07 & 0.597 & 0.000 & 42.56 \\
\hline Season ${ }^{\mathrm{a}}-$ Fall & & & & & & & & & & 0.142 & 0.002 & 5.68 \\
\hline Season ${ }^{\mathrm{a}}$-Spring & & & & & & & & & & -0.077 & & \\
\hline Crops, livestock ${ }^{\mathrm{b}}$ & -0.072 & 0.015 & 1.63 & & & & -0.086 & 0.014 & 1.47 & & & \\
\hline Pets $^{\mathrm{c}}$ & 0.015 & 0.041 & 0.82 & & & & 0.017 & 0.045 & 0.74 & & & \\
\hline Fire damage $^{\mathrm{d}}$ & & & & & & & 0.270 & 0.084 & 0.11 & & & \\
\hline$R^{2}$ of overall model & & & 72.82 & & & 46.50 & & & 77.39 & & & 48.24 \\
\hline
\end{tabular}

Refer to Table 1 for definitions.

$\mathrm{NR}=$ near river.

${ }^{\text {a }}$ Season is relative to summer. Given $p$ value and $R^{2}$ difference are for the season variable.

"A "yes", answer to the question, "Did you ever live on a property where any type of crops, livestock or poultry were raised?"

"A "yes" answer to the question, "Did you ever live on a property where pets frequently went in and out of your home?"

"A "yes", answer to the question, "Was a property that you lived in ever damaged by a fire while you lived there?"

to the $R^{2}$ of models with $\log _{10}$ of the vegetation as the outcome variable was the $\log _{10}$ concentration of the surrounding soil. The degree of similarity in congener patterns between the soil and vegetation, as evidenced by the values for the $\cos \theta$ parameter, further indicated that the principal contributor to the vegetation contamination was the soil. Because the dioxin and furan congeners tested in the linear regression were both lesser chlorinated congeners, the $\cos \theta$ analysis also suggested that the mechanism is deposition rather than uptake or volatilization.

The results for PCB 126, the dominant contributor to the soil TEQ in Jackson/Calhoun, seemed to differ from those for 2,3,7,8-TCDD, the dominant contributor to the soil TEQ in the plume, and $2,3,4,7,8-\mathrm{PeCDF}$, the dominant contributor to the soil TEQ in the floodplain. The ratio between the vegetation and soil concentrations for PCB 126 was 0.6. Furthermore, the values of $\beta$ for the region variable were smaller and predominantly negative, suggesting that the association between the PCB contamination in the soil and the grass in the Midland/ Saginaw regions is less strong, raising the possibility of alternate or additional mechanisms of PCB contamination such as atmospheric deposition and partitioning.

The results of the sampling of the vegetation around residences show that if the soil is contaminated, the vegetation may also become contaminated through deposition of the soil. The grass around the residences appeared to have considerably higher concentrations than the garden vegetables, although the number of vegetables sampled was small. However, this conclusion is supported by other studies [3] that reported higher concentrations for hay versus lettuce, for example. Models based on atmospheric deposition and partitioning have been noted to work well for fresh fruit and above-ground green vegetables [11], but they underpredict the concentrations of PCDDs and PCDFs in grass $[11,12]$. The results of this research suggest that the deposition of soil particles onto vegetation is a significant route of contamination for residential herbage. Thus, the inclusion of the deposition of soil particles onto vegetation may be critical to the accurate modeling of contamination residential herbage in communities impacted by historic industrial discharges of persistent organic compounds.

\section{SUPPLEMENTAL DATA}

Table S1. (108 KB PDF).
Acknowledgement-Financial support for this study comes from the Dow Chemical Company through an unrestricted grant to the University of Michigan. The authors thank Linda Birnbaum, Paolo Boffetta, Ronald Hites, David Kleinbaum, and Marie Haring Sweeney for their guidance as members of UMDES's Scientific Advisory Board.

\section{REFERENCES}

1. Whitehead D. 1968. The Dow Story. McGraw-Hill, New York, NY, USA.

2. Demond A, Adriaens P, Towey T, Chang S-C, Hong B, Chen Q, Chang C-W, Franzblau A, Garabrant D, Gillespie B, Hedgeman E, Knutson K, Lee C-Y, Lepkowski J, Olson K, Ward B, Zwica L, Luksemburg W, Maier M. 2008. Statistical comparison of residential soil concentration of PCDDs, PCDFS, and PCBs from two communities in Michigan. Environ Sci Technol 42:5441-5448.

3. Hulster A, Marschner H. 1993. Transfer of PCDD/PCDF from contaminated soils to food and fodder crop plants. Chemosphere 27:439-446.

4. Hulster A, Muller JF, Marschner H. 1994. Soil-plant transfer of polychlorinated dibenzo-p-dioxins and dibenzofurans to vegetables of the cucumber family (Cucurbitaceae). Environ Sci Technol 28:11101115.

5. Trapp S, Matthies M. 1997. Modeling volatilization of PCDD/F from soil and uptake into vegetation. Environ Sci Technol 31:71-74.

6. Simonich S, Hites R. 1995. Organic pollutant accumulation in vegetation. Environ Sci Technol 29:2905-2914.

7. Welsh-Pausch K, McLachlan MS, Umlauf G. 1995. Determination of the principal pathways of polychlorinated dibenzo- $p$-dioxins and dibenzofurans to Lolium multiflorum (welsh ray grass). Environ Sci Technol 29:1090-1098.

8. Schuhmacher M, Granero S, Rivera J, Muller L, Llobet JM, Domingo JL. 2000. Atmospheric deposition of PCDD/Fs near an old municipal solid waste incinerator: Levels in soil and vegetation. Chemosphere 40:593600.

9. Lovett AA, Foxall CD, Creaser CS, Chewe D. 1997. PCB and PCDD/DF congeners in locally grown fruit and vegetable samples in Wales and England. Chemosphere 34:1421-1436.

10. Wagrowski D, Hites R. 1998. Partitioning of polychlorinated dibenzo- $p$ dioxins and dibenzofurans between the atmosphere and corn. Environ Sci Technol 32:2389-2393.

11. Eduljee GH, Gair AJ. 1996. Validation of a methodology for modeling PCDD and PCDF intake via the foodchain. Sci Total Environ 187:211229.

12. Meneses M, Schuhmacher M, Domingo JL. 2002. A design of two simple models to predict $\mathrm{PCDD} / \mathrm{F}$ concentrations in vegetation and soil. Chemosphere 46:1393-1402.

13. Muller JF, Hulster A, Papke O, Ball M, Marschner H. 1994. Transfer of PCDD/PCDF from contaminated soils into carrots, lettuce and peas. Chemosphere 29:2175-2181.

14. Prinz B, Krause GHM, Radermacher L. 1990. Criteria for the evaluation of dioxins in vegetable plants and soil. Organohalogen Compounds 1990:595-600. 
15. Schuhmacher M, Nadal M, Domingo J. 2004. Levels of PCDD/Fs, PCBs and PCNs in soils and vegetation in an area with chemical and petrochemical industries. Environ Sci Technol 38:19601969.

16. Notarianni V, Calliera M, Tremolada P, Finizio A, Vighi M. 1998. PCB distribution in soil and vegetation from different areas in Northern Italy. Chemosphere 37:2839-2845.

17. U.S. Environmental Protection Agency. 2006. An inventory of sources and environmental releases of dioxin-like compounds in the United States for the years 1987, 1995, and 2000. EPA/600/P-03/002F. National Center for Environmental Assessment, Washington, DC.

18. Goovaerts P, Trinh H, Demond A, Franzblau A, Garabrant D, Gillespie B, Lepkowski J, Adriaens P. 2007. Geostatistical modeling and spatial distribution of soil dioxins in the vicinity of an incinerator, 1 . Theory and application to Midland, Michigan. Environ Sci Technol 42:36483654.

19. Garabrant D, Franzblau A, Lepkowski J, Gillespie B, Adriaens A, Demond A, Ward B, LaDronka K, Hedgeman E, Knutson K, Zwica L, Olson K, Towey T, Chen Q, Hong B. 2009. The University of Michigan Dioxin Exposure Study: Methods for an environmental exposure study of polychlorinated dioxins, furans and biphenyls. Environ Health Perspect 117:803-810.

20. U.S. Environmental Protection Agency. 1994. Method 8290: Polychlorinated dibenzodioxins (PCDDs) and polychlorinated dibenzofurans (PCDFs) by high-resolution gas chromatography/high-resolution mass spectrometry (HRGC/HRMS). Office of Solid Waste and Emergency Response, Washington, DC.
21. U.S. Environmental Protection Agency. 1999. Method 1668, Revision A: Chlorinated biphenyl congeners in water, soil, sediment, and tissue by high-resolution gas chromatography/high-resolution mass spectrometry (HRGC/HRMS). Office of Water, Washington, DC.

22. Van den Berg M, Birnbaum L, Denison M, De Vito M, Farland W, Feeley M, Fiedler H, Hakansson H, Hanberg A, Haws L, Rose M, Safe S, Schrenk D, Tohyama C, Tritscher A, Tuomisto J, Tysklind M, Walker N, Peterson RE. 2006. The 2005 World Health Organization reevaluation of human and mammalian toxic equivalency factors for dioxins and dioxinlike compounds. Toxicol Sci 93:223-241.

23. Hornung RW, Reed LD. 1990. Estimation of average concentration in the presence of nondetectable values. Appl Occup Environ Hygiene 5:46-51.

24. Gillespie B, Chen Q, Reichert H, Franzblau A, Hedgeman E, Lepkowski J, Adriaens P, Demond A, Luksemburg W, Garabrant D. 2010. Estimating population distributions when some data are below a limit of detection by using a reverse Kaplan-Meier estimator. Epidemiology 21:S64-S70.

25. Johnson G, Quensen J, Chiarenzelli J, Hamilton M. 2006. Polychlorinated biphenyls. In Murphy B, Morrison R, eds, Environmental Forensics: Contaminant Specific Guide. Academic, New York, NY, USA, pp 189-292.

26. Towey T, Chang S-C, Demond A, Wright D, Barabás N, Franzblau A, Garabrant D, Gillespie B, Lepkowski J, Luksemburg W, Adriaens P. 2010. Hierarchical cluster analysis of polychlorinated dioxins and furans in Michigan, USA, soils: Evaluation of industrial and background congener profiles. Environ Toxicol Chem 29:64-72. 